\title{
NOVO CÓDIGO DE PROCESSO CIVIL FLEXIBILIZAÇÃO DA COISA JULGADA E AÇÃO RESCISÓRIA NA EXECUÇÃO CONTRA Ả FAZENDA PÚBLICA
}

\author{
NEW CIVIL PROCEDURE CODE. SLACKEN OF RES JUDICATA AND THE \\ RESCISSION ACTION AGAINST THE NATIONAL TREASURY
}

\begin{abstract}
Alessandra Damian Cavalcanti
Advogada graduada pelo Uniceub, Pós-graduada em Direito Constitucional pelo IDP, mestranda em Direito Constitucional pelo Instituto Brasiliense de Direito Público - IDP

E-mail:alessandradamian@hotmail.com
\end{abstract}

Recebido em: 12/01/2017

Aprovado em: 04/02/2018

RESUMO: O presente trabalho pretende analisar alteração trazida pelo novo Código de Processo Civil, que trata sobre o cumprimento de sentença que reconheça a exigibilidade de obrigação de pagar quantia certa pela Fazenda Pública. O dispositivo prevê que serão inexigíveis as obrigações reconhecidas em título executivo judicial fundado em lei ou ato normativo tido pelo Supremo Tribunal Federal como incompatível com a Constituição Federal em controle concentrado ou difuso. O novo diploma legal trouxe a expressa ressalva de que a inexigibilidade da obrigação ocorre quando a decisão do Supremo Tribunal Federal tenha sido proferida antes da decisão exequenda transitar em julgado. No entanto, prevê uma nova hipótese de rescindibilidade, caso a decisão do Supremo Tribunal Federal ocorra após o trânsito em julgado da decisão, cujo prazo decadencial será contado a partir daquela decisão do Supremo e não da decisão exequenda. Evidencia-se a tensão entre segurança jurídica e coisa julgada inconstitucional. Em que medida a nova hipótese de rescindibilidade sem um prazo máximo estipulado entre a decisão exequenda e a decisão do Supremo Tribunal Federal harmoniza-se com a segurança jurídica? O presente trabalho analisa as categorias teóricas envolvidas por meio de pesquisa bibliográfica, bem como análise de decisão do Supremo Tribunal Federal sobre o tema. Conclui-se que a ausência de previsão de qualquer prazo máximo para que essa decisão transite em julgado soberanamente, pode causar insegurança jurídica e falta de efetividade nas decisões judiciais.

Palavras-Chave:Novo Código de Processo Civil. Flexibilização da coisa julgada. Segurança jurídica.

ABSTRACT: This study aims to examine a change brought by the new Civil Procedure Code, which deals with the execution of the sentence that recognizes the enforceability of the obligation to pay certain amount by the Treasury. The new law provides that the obligations are unenforceable if it was recognized in judicial enforcement based on normative law or act had by the Supreme Court as incompatible with the Constitution, in concentrated or diffuse control. The new Code brings an exception that the waiver of the obligation occurs when the decision of the Supreme Court has been rendered enforceable before the case will be heard. It provides, however, a new hypothesis of rescission if the decision of the Supreme Court take place after the final and unappealable decision, the res judicata. There is a clear tension between legal certainty and unconstitutional res judicata. To what extent the new hypothesis rescission if the decision of the 
Supreme Court take place after the final and unappealable decision, the limitation period shall be counted from that decision and not the decision enforceable. There is a clear tension between legal certainty and unconstitutional res judicata. To what extent the new hypothesis rescission harmonizes with legal certainty? This paper analyzes the theoretical categories involved through bibliographic research and decision analysis of the Supreme Court on the subject. The conclusion is that the lack of foresight of any deadline for the decision becomes final sovereignly, may cause legal uncertainty and lack of effectiveness in judicial decisions.

Keywords: New Civil Procedure Code. Slacken of res judicata. Accountability.

RESUMEN: Este estudio tiene como objetivo examinar el cambio producido en el nuevo Código de Procedimiento Civil, que trata de la ejecución de la sentencia que reconoce la aplicabilidad de la obligación de pagar cierta cantidad por el Tesoro. El dispositivo dispone que las obligaciones son inaplicables reconocido en la ejecución judicial basada en la ley o normativa acto contó por el Tribunal Supremo por ser incompatible con la Constitución de control concentrado o difuso y trae una nueva decisión de la hipótesis de la terminación inapelable. El nuevo Código trae la condición de que la exención de la obligación se produce cuando la decisión del Tribunal Supremo ha dictado exigible antes se escuchará el caso. Se prevé, sin embargo, una nueva hipótesis rescisoria si la decisión del Tribunal Supremo tiene lugar después de la decisión final e inapelable, el plazo de prescripción se cuenta a partir de esa decisión y no exigible decisión. Existe una clara tensión entre la seguridad jurídica y cosa juzgada inconstitucional. ¿En qué medida la nueva hipótesis para destronar la cosa juzgada armoniza con la seguridad jurídica? La falta de previsión de cualquier fecha límite para que la decisión sea soberanamente final puede causar inseguridad jurídica y falta de efectividad en las decisiones judiciales.

Palabrasclave: Nuevo Código de Procedimiento Civil. relativización de la cosa juzgada. seguridad jurídica.

SUMÁRIO:Introdução; I - Coisa Julgada; 1.1 Considerações sobre a relativização da coisa julgada; II - Ação Rescisória; 2.1 Decadência do direito à rescisão; III - Execução contra a Fazenda Pública; IV - Segurança Jurídica e a Coisa Julgada Inconstitucional; Conclusão; Referências

\section{INTRODUÇÃO}

O Novo Código de Processo Civil revela uma especial preocupação com a estabilidade, com a coerência e a com a integridade das decisões judiciais, de modo a promover uma maior segurança jurídica. A jurisprudência deve ser clara e coerente para que jurisdicionados, juízes, advogados e promotores saibam como pautar suas condutas e para que as demandas idênticas não tenham resultados díspares. A busca pela estabilidade das decisões judiciais é uma das grandes virtudes do novo diploma legal.

No entanto, para a jurisdição atender seus objetivos, os processos devem em determinado momento chegar ao fim, provendo uma decisão definitiva. Assim, para viabilizar a segurança jurídica, a demanda não pode se eternizar no tempo, surge então a importância do instituto da coisa julgada.

A intangibilidade da coisa julgada, entretanto, não é absoluta, pode ser, em determinados casos, objeto de ação rescisória. A ação rescisória é uma ação autônoma de impugnação, excepcional e sujeita a prazo e forma estabelecidos pela lei.

O Novo Código de Processo Civil traz significativas alterações no que tange a execução de quantia certa contra a Fazenda Pública, que agora dar-se-á em fase de cumprimento, como já ocorria nos casos de execução de sentença condenatória ao pagamento de quantia certa contra um 
particular. Mas não é só, o $\$ 5^{\circ}$ do art. 535 da Lei 13.105/201 prevê que é inexigível a obrigação reconhecida em título executivo judicial fundando em lei ou ato normativo considerado inconstitucional pelo Supremo Tribunal Federal ou fundado em aplicação ou interpretação da lei tida como incompatível com a constituição pelo Supremo Tribunal Federal.

Essa flexibilização já havia sido introduzida no Código de Processo Civil de 1973 pela Lei $n^{0} 11.232 / 2005$. Discutia-se na época se a decisão do Supremo Tribunal Federal que declarava a inconstitucionalidade de lei ou ato normativo, deveria ser anterior ao trânsito em julgado da decisão convertida em título executivo judicial, prestigiando a coisa julgada ou se o título seria inexigível até mesmo quando a decisão do Supremo Tribunal Federal tenha ocorrido após o trânsito em julgado da ação que deu origem àquela execução.

Essa questão foi respondida pelo Novo Código ao indicar no $\S 8^{\circ}$ do art. 535 que se a decisão do Supremo Tribunal Federal for proferida antes do trânsito em julgado da decisão exequenda o título será inexigível, caso a decisão seja proferida após o trânsito em julgado da decisão exequenda, caberá ação rescisória. O prazo para essa ação rescisória será contado somente a partir do trânsito em julgado da decisão proferida pelo Supremo Tribunal Federal que declare a inconstitucionalidade de lei ou ato normativo.

O presente trabalho pretende analisar essa nova hipótese de cabimento de ação rescisória trazida no $\S 8^{\circ}$ do art. 535 sob a ótica da segurança jurídica e da coisa julgada. Em que medida a flexibilização da coisa julgada e essa nova hipótese de ação rescisória garantem a estabilidade das relações e a pretendida segurança jurídica?

O Novo Código de Processo Civil entrou em vigor em março deste ano e em seu art. 1.057 estabelece que o $\$ 8^{\circ}$ do art. 535 aplicar-se-á somente às decisões transitadas em julgado após a sua entrada em vigor, para as decisões transitadas em julgado anteriormente, aplica-se o parágrafo único do art. 741 do Código de 1973.

A lide não pode se eternizar no tempo, as ações contra a Fazenda Pública são ações que têm uma tramitação lenta e demorada tanto no processo de conhecimento como na execução do julgado. A Jurisdição deve buscar a coerência, integridade e a estabilidade das decisões judiciais, sem mitigar a coisa julgada. A segurança jurídica deve ser preservada, sob pena de eternização dos conflitos e ineficácia da jurisdição.

A flexibilização da coisa julgada e sobretudo a possibilidade de ajuizamento de ação rescisória mesmo após vários anos do trânsito em julgado da decisão exequenda atenta contra a segurança jurídica e a estabilidade das relações.

O termo inicial do prazo decadencial para o ajuizamento da rescisória deveria ser contado a partir do trânsito em julgado da decisão rescindenda e não da decisão do Supremo Tribunal Federal ou deveria ser fixado um prazo máximo para que a decisão exequenda não possa mais ser modificada por decisões de inconstitucionalidade ocorridas após o decurso deste prazo. Caso a decisão do Supremo seja proferida quando já exaurido esse prazo máximo, conservar-se-á decisão inconstitucional, sob pena de fulminar-se por completo a segurança jurídica.

\section{I - COISA JULGADA}

Cada sistema jurídico define como se opera a coisa julgada, que se impõe por uma exigência prática, para que as disputas judiciais não se perpetuem indefinidamente e para que em algum momento tornem-se imutáveis. No Brasil, a Constituição Federal de 1988 garante no inciso XXXVI do art. $5^{\circ}$ que a lei não prejudicará o direito adquirido, o ato jurídico perfeito e a coisa julgada.

A coisa julgada é o elemento imunizador dos efeitos que a sentença projeta para fora do processo e que confere estabilidade a esses efeitos, impedindo que voltem a ser questionados 
depois de definitivamente estabelecidos por sentença não mais sujeita a recurso. (DINAMARCO, 2003, p. 33-34)

Assim, é preciso uma cláusula garantidora da estabilidade das decisões judiciais para que os cidadãos possam contar com certo grau de segurança na forma de conduzir e planejar as suas vidas. Os cidadãos devem poder confiar que as decisões incidentes sobre seus direitos se ligam a efeitos jurídicos duradouros, de confiança na manutenção das relações jurídicas constituídas, pela inalterabilidade da coisa julgada.

Canotilho destaca (2003, p. 264/265):

A segurança jurídica no âmbito dos actos jurisdicionais aponta para o caso julgado. $\mathrm{O}$ instituto do caso julgado assenta na estabilidade definitiva das decisões judiciais, quer porque está excluída a possibilidade de recurso ou a reapreciação de questões já decididas e incidentes sobre a relação processual dentro do mesmo processo - caso julgado formal -, quer porque a relação material controvertida (questão de mérito, questão de fundo) é decidida em termos definitivos e irretratáveis. [...] o princípio da intangibilidade do caso julgado é considerado como subprincípio inerente ao princípio do Estado de direito na sua dimensão de princípio garantidor de certeza jurídica.

Em Portugal, o caso julgado não está expresso no texto constitucional, mas é subprincípio inerente ao Estado de Direito.

Na Alemanha, a coisa julgada é consequência do Estado de Direito, tendo a garantia da certeza do direito como um componente essencial, que exige não apenas o desenvolvimento regular do processo, mas também a estabilidade da sua conclusão. (MARINONI, 2008b, p. 64)

No Brasil, essa garantia assegura que existe um limite ao poder do Estado, os atributos que caracterizam a coisa julgada, notadamente a imutabilidade dos efeitos inerentes à decisão judicial transitada em julgado, recebem, expressamente, da Constituição especial proteção destinada a preservar a inalterabilidade dos pronunciamentos emanados dos Juízes e Tribunais, criando, desse modo, situação de certeza, de estabilidade e de segurança para as relações jurídicas.

A Constituição Federal buscou valorizar a estabilidade das decisões judiciais de tal forma que obstou até mesmo o legislador ordinário de editar normas que afrontem os casos já decididos pelo Judiciário. Nota-se, que o instituto da coisa julgada possui assento constitucional como garantia do Estado à parte que litigou e teve proferida decisão de mérito. Portanto, o desrespeito à coisa julgada, não é apenas uma violação de índole processual, mas representa sobretudo afronta a uma garantia constitucional. (PORTO, 2006, p. 59)

Embora a definição da amplitude da coisa julgada encontre algumas divergências na doutrina, ela se caracteriza pela estabilidade da declaração jurisdicional, de forma imutável, a coisa julgada material impede que o Judiciário novamente se pronuncie sobre aquilo que já foi decidido.

Para Liebman (2006, p.5), a coisa julgada deve ser compreendida como uma qualidade, como um atributo para explicar a imutabilidade, a definitividade, a intangibilidade, a incontestabilidade da decisão.

Entretanto, a garantia de proteção à coisa julgada material não impede que a lei "preordene regras para a sua rescisão mediante atividade jurisdicional". (SILVA, 2013, p. 438)

A imutabilidade não é absoluta, existe mecanismo legal que permite a alteração de decisão judicial transitada em julgado, em prazo e hipóteses determinadas. Assim, a ação rescisória, como ação autônoma de impugnação, é o meio hábil para rescindir a decisão judicial transitada em julgado, contaminada por vício grave elencado dentre suas hipóteses de rescindibilidade. 
Destaca-se ainda que uma das hipóteses de rescindibilidade é a ofensa à coisa julgada na forma do inciso IV do art. 485 do Código de Processo Civil de 1973, bem como do inciso IV do art. 966 do Novo Código de Processo Civil, isto é, o legislador considera um grave vício uma decisão de mérito transitada em julgado que viole a coisa julgada. 


\subsection{Considerações sobre a relativização da coisa julgada}

Além da possibilidade de impugnação da coisa julgada por meio de ação rescisória, a Lei no 11.232/2005 que alterou no Código de Processo Civil de 1973, trouxe uma hipótese de relativização da coisa julgada.

Com a inclusão do parágrafo único do art. 741 no Código de 1973, que previa a inexigibilidade do título judicial baseado em lei tida por inconstitucional pelo Supremo Tribunal Federal, relativizou-se o instituto da coisa julgada.

O Novo Código de Processo Civil mantém essa previsão no $\$ 5^{\circ}$ do art. 535, mas faz expressamente a ressalva, no $\$ 7^{\circ}$ do mesmo dispositivo, de que o título executivo será inexigível se a decisão do Supremo Tribunal Federal ocorrer até o trânsito em julgado da ação exequenda. Se a decisão for posterior, caberá ação rescisória por parte da União de acordo com o $\$ 8^{\circ}$ do art. 535.

A relativização da coisa julgada é defendida por parte da doutrina: Humberto Theodoro Junior, Juliana Cordeiro de Faria, Cândido Rangel Dinamarco, Alexandre Freitas Câmara, entres outros, com fundamento na ideia de supremacia da Constituição e de que o princípio da intangibilidade da coisa julgada não é absoluto (CALDEIRA, 2012, p. 28/29).

O princípio da moralidade, o princípio da proporcionalidade e a justiça da decisão são outros argumentos utilizados pela doutrina favorável à relativização da coisa julgada.

A superação da coisa julgada ou do princípio que sustentou a decisão não pode ocorrer pela superação desta regra em detrimento do princípio da moralidade, pois para tanto teriam que ser superados também os princípios que estabeleceram a regra, que são os princípios da segurança jurídica e do Estado de Direito.

Para Ovídio Baptista (2003, p. 26) pressupor que a coisa julgada seja eficaz

somente quando não se confrontar com algum princípio constitucional, ou com os princípios normativos de grau inferior - testando sua validade a partir de sua "legalidade" - é submetê-la a uma premissa impossível de ser observada.

A proporcionalidade não é um princípio, esta divide-se em três sub-regras: adequação, necessidade e proporcionalidade em sentido estrito. A alegação de que a decisão protegida pela coisa julgada fere o princípio da proporcionalidade, não pode ser utilizada como mais um argumento retórico. A aplicação da regra da proporcionalidade deve observar a ordem prédefinida pela qual as sub-regras se relacionam. A adequação precede a necessidade, que, por sua vez, precede a proporcionalidade em sentido estrito. A importância desse procedimento fica patente quando se tem em mente que a aplicação da proporcionalidade nem sempre implica a análise de todas as suas três sub-regras. A análise da proporcionalidade em sentido estrito somente é imprescindível se o problema já não tiver sido solucionado com as análises da adequação e da necessidade. (SILVA, 2002, p. 35/41)

Assim, é difícil que a proporcionalidade seja o argumento para rescindir uma decisão judicial transitada em julgado considerada injusta.

Sobre a (in)justiça da decisão, colocada em contraste com a segurança jurídica, parece que o Constituinte tenha optado pelo valor da segurança jurídica e da estabilidade das relações jurídicas decorrentes das decisões judiciais transitadas em julgado, conforme expresso no inciso XXXVI do Art. $5^{\circ}$ da Constituição Federal.

Para a Constituição Federal de 1988 é mais grave a insegurança causada pela relativização da coisa julgada do que a existência de decisões injustas.

Araken de Assis (2002, p. 27) destaca que "parece pouco provável que as vantagens da justiça do caso concreto se sobreponham às desvantagens da insegurança geral." 
Nesse mesmo sentido, Fredie Didier Júnior (2007, p. 505), Luiz Guilherme Marinoni (2008, p. 696), Barbosa Moreira (2005, p. 43), Ovídio Baptista (2006), Marcus Flávio Horta Caldeira (2012, p. 38), posicionam-se contra a relativização da coisa julgada, sob pena de jamais chegar ao fim dos processos, comprometendo sobremaneira a segurança jurídica.

Para Ovídio Baptista (2006):

Como já dissera Karl Marx, numa frase que se tornou célebre, a modernidade faz com que "tudo o que seja sólido desmanche no ar". As coisas que pareciam perenes, mesmo as coisas sagradas, ou aquelas tidas como naturais, como a família, acabam desfazendo-se, ante a voracidade das transformações culturais. É de supor que estejamos vivendo a fase terminal do ciclo histórico que, suplantando a Idade Média, deu nascimento à modernidade. Certamente ainda somos "modernos", mas participamos do que Bauman, um dos mais instigantes sociólogos contemporâneos, denomina "modernidade líquida", contrapondo-a à "primeira modernidade". Enquanto a que fora objeto da observação de Marx destruía todos os sólidos, porém para recompô-los, criando novas verdades, com igual pretensão à perenidade, a "modernidade líquida" compraz-se em tudo desfazer, "desmanchar" o que fora a novidade da véspera, sem que nada permanente seja construído. Tudo o que nossa "modernidade líquida" é capaz de construir nasce com o selo da provisoriedade, para ser logo demolido.

Neste quadro cultural, não deve surpreender que a instituição da coisa julgada, tida como sagrada na "primeira modernidade", entre em declínio. O fenômeno obedece à lei que tem presidido o mundo moderno. Não deixa, porém, de ser curioso que o ataque à coisa julgada provenha da própria modernidade, levando em conta que a instituição fora concebida para atender à exigência primordial de segurança jurídica, condição básica para o desenvolvimento econômico, aspiração também moderna.

Ovídio Baptista (2006) salienta que a coisa julgada, antes de ser "uma elucubração teórica, teve sua origem em casos judiciais concretos, nascidos das experiências forenses" e aponta que a justificativa de relativização da coisa julgada com base "em grave injustiça" importa em perigosa indeterminação conceitual e assevera que pretender a desconsideração da coisa julgada toda vez que a sentença seja tida como "injusta” não é um ideal da modernidade.

Neste contexto, a coisa julgada é um instituto de natureza constitucional inerente ao próprio Estado Democrático de Direito como garantidor da segurança jurídica decorrente das causas submetidas ao Poder Judiciário.

Ao entender pela possibilidade de relativização no caso de "decisão injusta", como garantir-se-á que a sentença que reformar a anterior com base na suposta injustiça não venha ser questionada mais uma vez como injusta, qual seria o fim?

Por essas razões a simples relativização da coisa julgada causaria perigosa instabilidade no sistema jurídico. A ação rescisória é que deve ser o meio hábil para rescindir a decisão transitada em julgado em determinadas situações que devem estar elencadas taxativamente na legislação e com prazo e forma definidos.

\section{II - AÇÃO RESCISÓRIA}

A ação rescisória é uma derivação dos antigos institutos da querela nullitatis e da restitutio in integrum existentes no Direito Romano e no Direito Canônico. (SOUZA, 2011, p. 817)

A ação rescisória é definida como "a demanda autônoma de impugnação de provimentos de mérito transitados em julgado, com eventual rejulgamento da matéria neles apreciada." (CÂMARA, 2014, p. 19) 
Alexandre Freitas Câmara entende que a rescisória não é cabível para rescindir decisões injustas, tampouco funciona como um sucedâneo de recurso com um largo prazo de interposição, é medida que visa rescindir o pronunciamento judicial impugnado dentro das hipóteses de rescindibilidade $(2014$, p. 35/36).

A ação rescisória é demanda destinada a rescindir decisões que contenham vícios gravíssimos, por isso o rol das hipóteses de rescindibilidade previsto no Código de Processo Civil é taxativo, não havendo lugar para interpretação extensiva. (SOUZA, 2011, p. 827)

Bernardo Pimentel de Souza destaca que "a ação rescisória é verdadeira exceção no direito brasileiro, porquanto implica quebra da coisa julgada, instituto protegido à vista do Art. $5^{\circ}$, inciso XXXVI, da Constituição Federal. Daí a justificativa para a interpretação estrita das hipóteses de rescindibilidade." (2011, p. 829)

\subsection{Decadência do direito à rescisão}

O direito de rescindir uma decisão judicial se extingue em dois anos, prazo mantido no art. 975 do Novo Código de Processo Civil.

Sobre a questão do prazo decadencial para propor a ação rescisória, Alexandre Câmara destaca que no direito comparado ainda que haja alguma divergência quanto ao prazo inicial, há um limite máximo para a revisão da coisa julgada (2014, p. 159):

No direito espanhol, o prazo para oferecimento de revisión é de três meses, contados da data da descoberta do fundamento do pedido. Jamais se admite, porém, a revisión mais de cinco anos após a publicação da sentença que se quer impugnar (art. 512 da Ley deenjuiciamiento civil). Semelhante é o sistema do direito uruguaio, em que a revisión pode ser proposta até três meses depois da descoberta do fundamento do pedido, mas nunca depois de um ano do início da produção dos efeitos da sentença (art. 285 do Código General del Processo).

No direito português o prazo para oferecimento do recurso de revisão é de sessenta dias, cujo termo inicial varia conforme o fundamento do pedido, mas jamais depois de cinco anos do trânsito em julgado da decisão que se quer impugnar (art. $697^{\circ}$ do Código de Processo Civil português)

O Novo Código trouxe uma modificação em relação à ação rescisória fundada em prova nova, cuja existência o autor ignorava ou não pode fazer uso, hipótese prevista no inciso VII do art. 966. Nesse caso, o termo o quo para a contagem do prazo para a ação rescisória será da descoberta da nova prova, observado o prazo de cinco anos contados no trânsito em julgado do processo.Dessa forma, passados cinco anos do trânsito em julgado, ainda que surjam novas provas, a decisão não pode mais ser rescindida, ou seja, tornar-se-á definitivamente imutável.

Entretanto, ao tratar sobre o cumprimento de sentença que reconheça a exigibilidade de obrigação de pagar quantia certa pela Fazenda Pública, a previsão contida no $\S 8$ do art. 535 do Código de Processo Civil de 2015 estabelece a possibilidade de ajuizamento de ação rescisória quando a decisão exequenda se fundar em lei ou ato normativo julgado inconstitucional pelo Supremo Tribunal Federal. O prazo decadencial contará a partir do trânsito em julgado da decisão do Supremo Tribunal Federal e não da decisão exequenda, não há, neste caso, prazo máximo estipulado para que a decisão exequenda não possa mais ser rescindida.

Para Nelson Nery Júnior:

A pretensão rescisória extinta pela decadência não pode renascer pela decisão futura do STF. Saliente-se que a ADIn, por exemplo, não tem prazo de exercício previsto em lei, de sorte que se trata de pretensão perpétua, que pode ser ajuizada dois, cinco, dez, vinte anos depois da entrada em vigor da lei apontada inconstitucional. Por óbvio, a rescisória - instituto que se caracteriza como 
exceção à regra constitucional da intangibilidade da coisa julgada material $(\mathrm{CF}$ $5^{\circ}$. XXXVI), que, como exceção, deve ser interpretada restritivamente - não pode receber esse mesmo tratamento e nem as partes devem submeter-se à essa absoluta insegurança jurídica. (2016, p. 1.442/1.443)

Extinta a pretensão rescisória pela decadência, não poderia começar a correr novamente em razão da superveniência de acórdão do Supremo Tribunal Federal, entendimento diverso ofende o princípio constitucional da segurança jurídica e a garantia fundamental da intangibilidade da coisa julgada (NERY JÚNIOR, 2016, p. 1443).

\section{III - EXECUÇÃO CONTRA A FAZENDA PÚBLICA}

A expressão Fazenda Pública tradicionalmente utilizada como a área da Administração Pública que trata da gestão das finanças públicas, mas com o uso frequente do termo em um sentido mais amplo passou a significar a personificação do Estado em juízo, abrangendo as pessoas jurídicas de direito público. Assim, no processo em que haja a presença de uma pessoa jurídica de direito público, esta é designada genericamente, como Fazenda Pública. (CUNHA, 2012, p. 15)

A representação judicial da União é feita pela Advocacia-Geral da União, nos termos da Lei Complementar no 73/1993 e art. 182 do Novo Código de Processo Civil.

A Advocacia Pública goza de prazo em dobro para todas as suas manifestações processuais, contados a partir de sua intimação pessoal, nos termos do art. 183 do Novo Código de Processo Civil. O art. 188 Código de Processo Civil de 1973, previa o prazo em dobro para recorrer e em quádruplo para contestar para a Fazenda Pública.

As prerrogativas em relação aos prazos para a Advocacia Pública já foram objeto de discussão no Supremo Tribunal Federal justamente no que tange o prazo para o ajuizamento de ação rescisória. A Medida Provisória $\mathrm{n}^{\circ}$ 1.577/1997, duplicou o prazo decadencial para o ajuizamento de ação rescisória pela Fazenda Pública e em reedição (MP 1.577-6/1997) ampliou para cinco anos.

O Supremo Tribunal Federal em sede de ação direta de inconstitucionalidade, ADI 1.753/DF, deferiu medida cautelar para suspender a vigência do referido dispositivo.

Excepcionalmente, o Supremo Tribunal Federal adentrou aos critérios de urgência e relevância da edição da referida medida provisória, por entender que não havia como sustentar o caráter urgente de medida que alterasse a disciplina legal da ação rescisória e restou destacado no julgado (ADI 1.753-2/DF, DJ 12/06/2008, p. 40):

A igualdade das partes é imanente ao procedural due processo of law; quando uma das partes é o Estado, a jurisprudência tem transigido com alguns favores legais que, além da vetustez, tem sido reputados não arbitrários por visarem a compensar dificuldades da defesa em juízo das entidades públicas; se, ao contrário, desafiam a medida da razoabilidade ou da proporcionalidade, caracterizam privilégios inconstitucionais: parece ser esse o caso das inovações discutidas, de favorecimento unilateral aparentemente não explicável por diferenças reais entre as partes e que, somadas a outras vantagens processuais da Fazenda Pública, agravam a consequência perversa de retardar sem limites a satisfação do direito do particular já reconhecido em juízo.

Em seu voto o ministro relator, Min. Sepúlveda Pertence, assevera: "Mas de duas, uma: ou há coisa julgada ou não há. ” E que

Parece claro que a questão é ainda mais espinhosa, quando se trata, como agora, não de diminuir, mas de ampliar o prazo de decadência da rescisão de sentenças 
já definitivas: é que à aplicação da lei nova se pode ainda opor, com seriedade, o constituir forma de enfraquecer a coisa julgada anterior com fraude ao princípio que a protege. (STF, ADI 1753-2/DF, p. 48/50)

O ministro destacou ainda que a disparidade do tratamento conferida pela norma à Fazenda Pública é mais agravada quando se considera que essa diferença no prazo majorado para a decadência do direito de ajuizar ação rescisória é mais um benefício somado a outras vantagens processuais da Fazenda Pública, todas elas com a "consequência perversa de retardar sem limites a satisfação do direito do particular reconhecido em juízo".

Embora o julgamento da medida cautelar na ADI $\mathrm{n}^{\circ} 1.753-2$ tenha combatido uma inconstitucionalidade muito mais flagrante do que a inconstitucionalidade promovida pela relativização da coisa julgada promovida pela Lei $n^{\circ} 11.232 / 2005$ e pela nova hipótese de cabimento de ação rescisória sem um prazo máximo em relação ao trânsito em julgado da decisão exequenda, as razões do julgamento daquela ação direta de inconstitucionalidade são relevantes para compreender como o Supremo Tribunal Federal tratava a questão da segurança jurídica.

\section{IV - SEGURANÇA JURÍDICA E A COISA JULGADA INCONSTITUCIONAL}

A coisa julgada garante a segurança das relações jurídicas, do contrário, os conflitos já decididos poderiam sofrer modificações a todo momento, a imutabilidade e intangibilidade protege o conteúdo das decisões judiciais transitadas em julgado.

O Poder Judiciário não está livre de comete erros e uma decisão judicial transitada em julgado pode conter vícios graves, o que poderá ser combatido por meio de ação rescisória, dentro das hipóteses taxativas de cabimento elencadas no Código de Processo Civil.

Entretanto, existe uma tensão entre a segurança jurídica e a coisa julgada inconstitucional. Em que medida o Estado Democrático deve privilegiar a coisa julgada, ainda que inconstitucional, em razão da segurança jurídica? Ou em que medida sacrificar a segurança jurídica para combater decisões inconstitucionais transitadas em julgado? Argumentos de justiça da decisão seriam suficientes para equalizar esse impasse?

O objeto da coisa julgada preocupa-se com a segurança das relações jurídicas, pacificando os conflitos, em regra, de forma definitiva.

Nenhum mecanismo processual é garantia de uma solução justa. O Código Processual adotou a coisa julgada para colocar um ponto final nos conflitos, não seria o próprio instituto da coisa julgada um mecanismo de justiça processual?

É justo com ambas as partes ter a ciência de que após um longo trâmite processual -- não há trâmite célere em uma realidade onde os números de processos aumentam em progressão geométrica e o Poder Judiciário não conta com a estrutura física ou de recursos humanos adequada para suprir essa demanda - chegar-se-á a uma decisão definitiva.

O legislador e o Supremo Tribunal Federal vinham conferindo um peso maior à segurança jurídica.

Embora seja louvável que o legislador institua mecanismos para a valorização dos precedentes do Supremo Tribunal Federal, contribuindo para a concretização de outros direitos fundamentais, como o direito à razoável duração do processo, não parece adequado que se possa alcançar esses objetivos em detrimento da proteção à coisa julgada, minando a segurança jurídica necessária a qualquer ordenamento (DELLORE, 2013).

O sopesamento em favor da segurança jurídica evidencia-se na modulação dos efeitos da decisão de inconstitucionalidade de lei ou de ato normativo, prevista no art. 27 da Lei $n^{\circ}$ 9.868/1999: 
Supremo Tribunal Federal, por maioria de dois terços de seus membros, restringir os efeitos daquela declaração ou decidir que ela só tenha eficácia a partir de seu trânsito em julgado ou de outro momento que venha a ser fixado.

O Supremo Tribunal Federal tem utilizado da modulação dos efeitos, em nome da segurança jurídica e da proteção da confiança: ${ }^{1}$

A modulação temporal das decisões em controle judicial de constitucionalidade decorre diretamente da Carta de 1988 ao consubstanciar instrumento voltado à acomodação otimizada entre o princípio da nulidade das leis inconstitucionais e outros valores constitucionais relevantes, notadamente a segurança jurídica e a proteção da confiança legítima, além de encontrar lastro também no plano infraconstitucional - Lei n 9.868/99, art. 27. (ADI 3106 ED/MG)

Então parece um contrassenso defender a ideia de que é possível que o Supremo Tribunal Federal ao declarar a inconstitucionalidade de lei ou ato normativo, tendo em vista razões de segurança jurídica, possa restringir os efeitos daquela declaração ou decidir que ela só tenha eficácia a partir de seu trânsito em julgado ou de outro momento que venha a ser fixado, e sustentar que no caso de declaração de inconstitucionalidade poderá ser ajuizada uma ação rescisória contra uma decisão transitada em julgado há mais de dez anos contra a Fazenda Pública, pois a coisa julgada não deve albergar as decisões inconstitucionais.

Se a modulação dos efeitos possibilita a manutenção dos efeitos de relações jurídicas baseadas no ato normativo ou na lei declarada inconstitucional em razão da segurança jurídica e proteção da confiança, as decisões transitadas em julgado merecem maior proteção contra decisões posteriores que declararem a inconstitucionalidade da lei utilizada para conceder a pretensão da parte, ou ao menos deveria haver a definição de um lapso temporal máximo para que a decisão transitada em julgado não possa mais ser modificada nem por ação rescisória.

A eficácia prospectiva à declaração de inconstitucionalidade demonstra que em nome da segurança jurídica é possível, em determinadas situações, manter a "inconstitucionalidade" sob pena de um prejuízo social maior com a retroatividade dos efeitos da declaração.

Nesse sentido, Gilmar Mendes já se pronunciou que:

[...] muitas vezes, a aplicação continuada de uma lei por diversos anos torna quase impossível a declaração de sua nulidade, recomendada a adoção de alguma técnica alternativa, com base no próprio princípio constitucional da segurança jurídica. Aqui, o princípio da nulidade deixa de ser aplicado com base no princípio da segurança jurídica. (2005, p. 305-331)

O Supremo Tribunal Federal no julgamento do Recurso Extraordinário 730.462/SP ${ }^{2}$ com repercussão geral reconhecida, reafirmou:

A declaração de inconstitucionalidade, como regra, tem o condão de produzir efeitos para todos (erga omnes), alcançando os atos pretéritos eivados do vício de nulidade (ex

\footnotetext{
${ }^{1}$ Algumas decisões do Supremo Tribunal Federal que julgaram em controle abstrato a inconstitucionalidade de dispositivos legais ou atos normativos e modularam os efeitos da decisão para regular as relações jurídicas afetadas pelas normas impugnadas: ADI 3106 ED /MG, julgamento 20/05/2015, relator Min. Luiz Fux, acórdão publicado no DJe 158, 13/08/2015; ADI 4171/DF, julgamento 20/05/2015, relatora Min. Ellen Gracie, registrado o acórdão pelo Min. Lewandowski, acórdão publicado no DJe de 21/08/2015; ADI 4425 QO/DF, julgamento 25/03/2015, relator Min. Luiz Fux, acórdão publicado no DJe de 04/08/2015.

${ }^{2}$ Trata-se do Tema 733 da Repercussão Geral. O Plenário do Supremo Tribunal Federal julgou a matéria em $28 / 05 / 2015$ Disponível $\langle$ http://www.stf.jus.br/portal/processo/verProcessoAndamento.asp?incidente $=4353441$ > $>$. Compulsado em $17 / 08 / 2016$
} 
tunc). Não significa dizer, contudo, que a retroatividade possa alcançar, inclusive, as decisões judiciais transitadas em julgado, sob pena de propiciar insegurança nas relações sociais e jurídicas.

$\mathrm{Na}$ referida decisão restou ressaltada a diferença entre duas espécies de eficácia, a eficácia normativa e a eficácia executiva, em razão as consequências que operam em face das situações concretas. Enquanto a eficácia normativa se opera ex tunc, a eficácia executiva é diferente, sobretudo em relação aos atos pretéritos.

No caso das decisões transitadas em julgado há mais de 2 anos, ainda que com a declaração de inconstitucionalidade superveniente, entendeu a Corte que existe uma espécie de modulação ope legis dessas decisões, que embora formados com base em preceito normativo declarado inconstitucional e excluído do ordenamento jurídico, não ficam sujeitos aos efeitos da declaração de inconstitucionalidade.

No julgamento do Recurso Extraordinário $n^{\circ} 730.462$ durante os debates os ministros discutem sobre a relativização da coisa julgada. O Min. Marco Aurélio ressalta que a coisa julgada "é um ato jurídico perfeito e acabado por excelência" e que "a única relativização quanto a ela diz respeito à própria Carta da República, no que prevê a ação de impugnação autônoma, a rescisória. Não há outra possibilidade de flexibilizar o instituto. ” (p. 20)

Na sequência, o Min. Luiz Fux destaca (p. 21):

[...] só vou fazer uma pequena observação, porque essa matéria, depois que houve a alteração do Código de Processo Civil - é atual em vigor o de 73 -, tornou-se muito controvertida, porque a Fazenda Pública entendia que, quando do advento da declaração de inconstitucionalidade, se poderia desconstituir a sentença mesmo depois do processo em execução. Então, o novo Código traz uma solução bem prática. Se a lei for declarada inconstitucional antes do trânsito em julgado da sentença que fundamentou aquela decisão, com base naquela lei, é possível arguir em embargos do executado a inconstitucionalidade. Se a declaração de inconstitucionalidade surge depois do trânsito em julgado, é preciso, efetivamente, promover uma ação rescisória, e, evidentemente, que a estratégia é a promoção da ação rescisória com pedido de suspensão da execução.

Para o Ministro Celso de Mello (p. 25):

Torna-se importante destacar, neste ponto, tal como fiz consignar em referido julgamento, o alto significado de que se reveste, em nosso sistema jurídico, o instituto da "res judicata", que constitui atributo específico da jurisdição e que se projeta na dupla qualidade que tipifica os efeitos emergentes do ato sentencial: a imutabilidade, de um lado, e a coercibilidade, de outro.

A proteção constitucional dispensada à coisa julgada em sentido material revelase tão intensa que impede sejam alterados os atributos que lhe são inerentes, a significar, como já salientado, que nenhum ato estatal posterior poderá, validamente, afetar-lhe a integridade.

$[\ldots]$

Na realidade, a desconsideração da "auctoritas rei judicatae" implicaria grave enfraquecimento de uma importantíssima garantia constitucional que surgiu, de modo expresso, em nosso ordenamento positivo, com a Constituição de 1934.

A pretendida "relativização" da coisa julgada - tese que tenho repudiado em diversos julgamentos (monocráticos) proferidos no Supremo Tribunal Federal (RE 554.111/RS - RE 594.350/RS - RE 594.892/RS - RE 594.929/RS - RE $595.565 / \mathrm{RS})$ - provocaria consequências altamente lesivas à estabilidade das 
relações intersubjetivas, à exigência de certeza e de segurança jurídicas e à preservação do equilíbrio social.

Os atributos que caracterizam a coisa julgada, principalmente a imutabilidade dos efeitos da decisão judicial transitada em julgado, recebem diretamente da Constituição Federal especial proteção, destinada a preservar a estabilidade e a segurança jurídica para as relações jurídicas.

No entanto, no julgamento da ADI $2418 / \mathrm{DF}^{3}$ se reconheceu, por maioria, a constitucionalidade do parágrafo único do art. 741 do Código de Processo Civil de 1973, bem como dos artigos correspondentes no Novo Código de Processo Civil de 2015 - art. 535, §5 Ocorre que na referida decisão não se aprofundou sobre do prazo para o ajuizamento da ação rescisória e sobre a ausência de estipulação no Novo Código de um prazo máximo para que a decisão exequenda não pudesse mais ser modificada, ainda que o Supremo Tribunal Federal posteriormente julgue a inconstitucionalidade de lei ou ato normativo utilizado em sua fundamentação.

Enfim, em algum momento a decisão judicial transitada em julgado, mesmo que seja inconstitucional, deverá se tornar definitiva, não parece ser razoável a ausência de fixação de um prazo máximo definido para que uma declaração superveniente de inconstitucionalidade a atinja.

Como destaca Luiz Dellore:

A solução legislativa, se aplicada de forma a possibilitar a desconsideração da coisa julgada formada anteriormente a reconhecimento de inconstitucionalidade pelo STF, ignora que a questão da constitucionalidade encontra-se abrangida pela eficácia preclusiva da coisa julgada [...] a possibilidade de, a qualquer tempo, regressar à discussão da causa decidida pela sentença, alimentando o egoísmo do perdedor, faz com que o processo se transforme em um fim em si mesmo, um fim oco e vazio. (2013, p. 195)

\section{CONCLUSÃO}

Conclui-se então que, para que a jurisdição alcance seus objetivos, o processo deverá chegar ao fim em algum momento determinado, produzindo uma decisão definitiva sobre a demanda. Do contrário, as demandas se eternizariam e não teriam nenhuma utilidade, pois os cidadãos buscariam outras formas para a solução dos seus conflitos.

A coisa julgada é a ferramenta que garante a imutabilidade do provimento judicial, constitui garantia constitucional nos termos do inciso XXXVI do Art. $5^{\circ}$ da Constituição Federal e promove a segurança jurídica, fundamental no Estado de Direito.

A relativização da coisa julgada configura uma ameaça ao próprio instituto da coisa julgada, admitir que mesmo a declaração de inconstitucionalidade de uma norma, tem o condão de afastar a coisa julgada que com base nela se formou é medida perigosa, que gera insegurança jurídica e prejudica a estabilidade das relações sociais.

\footnotetext{
${ }^{3}$ O Supremo Tribunal Federal julgou em 04/05/2016 a ADI 2.418/DF ajuizada pelo Conselho Federal da OAB. O Min. Teori Zavascki, relator da ação, entendeu ser constitucional o parágrafo único do art. 741 do CPC 73 e seus correspondentes no $\mathrm{CPC} / 15$, interpretando que a inexigibilidade seria aplicada somente quando o STF declara a inconstitucionalidade utilizada como fundamento para a decisão antes do trânsito em julgado da decisão exequenda. O Min. Celso de Mello consignou em seu voto que é contra a possibilidade de revisão do julgamento após o prazo da ação rescisória, ainda que a norma venha depois a ser declarada inconstitucional. Os ministros Edson Fachin, Luiz Barroso e Rosa Weber ressaltaram algumas dúvidas sobre a constitucionalidade dos dispositivos correspondentes no novo CPC, que prevê o transito em julgado da decisão do STF como termo inicial para o cômputo do prazo decadencial para o ajuizamento da ação rescisória. O ministro Marco Aurélio ficou parcialmente vencido, pois defende a soberania da coisa julgada. Por maioria o STF julgou improcedente a ADI. O acórdão ainda não foi publicado.
} 
Seja nas execuções promovidas contra a Fazenda Pública na égide do Código de 1973 ou no cumprimento de sentença como previsto no Novo Código de Processo Civil, certamente tratam-se de processos que tramitaram por longos anos durante a fase de conhecimento e por mais vários anos para se viabilizar a execução do julgado, processos que podem até ter sido julgados pelo Supremo Tribunal Federal, sem qualquer inconstitucionalidade detectada até aquele momento. A relativização da coisa julgada, na forma do parágrafo único do Art. 741 do Código de Processo Civil de 1973 e no $\$ 5^{\circ}$ do Art. 535 do Novo Código de Processo Civil não parece ser medida compatível com a segurança jurídica.

Em relação ao início da contagem do prazo para o ajuizamento de ação rescisória na forma do $\S 8^{\circ}$ do Art. 535 do NCPC, não há qualquer menção a um possível limite máximo para que essa situação ocorra, o que gera mais insegurança em relação às decisões judiciais.

Por exemplo, um processo coletivo de uma categoria de servidores que busca determinada vantagem ou benefício pela via judicial, digamos que o processo de conhecimento tenha demorado 20 anos até o trânsito em sede de recurso extraordinário, ou seja, já foi apreciado pelo Supremo Tribunal Federal, suponhamos que a execução do julgado já perdure por 5 anos. Pois bem, transcorridos 25 anos de tramitação judicial o Supremo Tribunal Federal, com nova composição, decida em sede de controle difuso que aquele benefício é inconstitucional.

Teremos a seguinte situação, processo transitado em julgado há mais de 5 anos, esgotado prazo de ação rescisória de acordo com o Código de 1973, de acordo com o art. 1.057 do NCPC neste caso não se aplicará o disposto no $\$ 8^{\circ}$ do Art. 535, mas o parágrafo único do Art. 741 da legislação anterior, julgado constitucional pelo Supremo Tribunal Federal na ADI 2418/DF.

Assim, mesmo depois de 25 anos de tramitação, já tendo transcorrido 5 anos da data do trânsito em julgado da decisão exequenda, o título passará a ser considerado inexigível. O mesmo aconteceria se o trânsito em julgado já tivesse 10, 15 ou 20 anos pois não há limite máximo estabelecido para essa relativização. A qualquer momento o Supremo Tribunal Federal poderá decidir matérias em controle difuso que não afetarão apenas os processos em andamentos, mas todos aqueles que já transitaram em julgado, independentemente de quanto tempo já tenha transcorrido entre o trânsito em julgado e a decisão superveniente do Supremo Tribunal Federal.

Ainda que o Novo Código tenha restringido a relativização da coisa julgada em relação ao que previa o parágrafo único do art. 741 do diploma anterior, permanece uma situação de insegurança jurídica, mesmo que em menor grau.

Agora, com a nova regra, a inexigibilidade do título com base em decisão do Supremo Tribunal Federal que ocorrer após o trânsito em julgado da decisão exequenda, dependerá de ação rescisória, com prazo contado a partir do trânsito em julgado da decisão do Supremo Tribunal Federal e não do trânsito da decisão exequenda.

Essa situação indeterminada quanto ao prazo máximo para que isso ocorra nos parece inconstitucional, veja que em outras situações onde ocorrem nulidades, a legislação estabelece um lapso temporal máximo para o desfazimento do ato. Como ocorre a previsão contida no Art. 54 da Lei no 9.784/99, que prevê que o direito da Administração de anular seus próprios atos quando eivados de vícios de legalidade, decai em 5 anos contados da data em que foram praticados, salvo comprovada má-fé.

Cumpre observar que no caso da ação rescisória fundada em prova nova prevista no inciso VII do Art. 966 do NCPC, terá como início do prazo a descoberta da prova nova. Entretanto, esse prazo não é ilimitado, o §2 do Art. 975 prevê que deverá ser observado o prazo máximo de 5 anos contados do trânsito em julgado da última decisão proferida no processo, isto é, caberá rescisória no caso de prova nova descoberta 4 anos após o trânsito em julgado, mas não caberá rescisória se essa nova prova for descoberta depois de 6 anos que a decisão transitou.

No caso da previsão de ação rescisória nos casos de execução contra a Fazenda Pública, contar-se-ão dois anos do trânsito em julgado da decisão do Supremo Tribunal Federal, seja 
quando for, mesmo que já tenha transcorrido um largo lapso temporal entre esta e o trânsito da decisão exequenda.

A parcela da doutrina que defende a relativização da coisa julgada nos casos de declaração de inconstitucionalidade superveniente pelo Supremo Tribunal Federal baseia-se em argumentos de justiça. Mas isso é justo? Uma situação que a decisão judicial transitada em julgado pode ser modificada a qualquer tempo, sem que haja um prazo máximo para essa modificação?

Para os processos que ainda não transitaram em julgado, o Novo Código de Processo Civil de fato diminuiu a amplitude essa relativização, pois passa a prever não apenas a simples relativização com a consequente inexigibilidade do título, como previa o diploma anterior, situação que continuará sendo aplicada para todos os processos que transitaram em julgado antes da entrada em vigor do NCPC. Nos cumprimentos de sentença contra a Fazenda Pública cujas decisões exequendas transitarem em julgado já na égide do Novo Código, o $\$ 8^{\circ}$ do Art. 535 prevê que caberá ação rescisória cujo prazo será contado do trânsito em julgado da decisão proferida pelo Supremo Tribunal Federal, ou seja, contam-se dois anos a partir do trânsito em julgado, independentemente se ocorrido 5 ou 15 anos após o trânsito em julgado da decisão exequenda.

Em defesa da segurança jurídica é preciso que sejam estabelecidos prazos a partir dos quais as decisões não possam mais ser modificadas, para preservar o instituto da coisa julgada. Não é possível que o jurisdicionado fique ad eternum sem saber se uma decisão judicial é definitiva ou não. O desprestígio à coisa julgada é uma afronta à Constituição, a falta de segurança jurídica desestabiliza as relações sociais. Em algum momento os julgamentos devem ser definitivos. A ideia de relativização da coisa julgada e da ação rescisória que pode ser ajuizada a qualquer tempo não é compatível com a estabilidade pretendida pelo Novo Código de Processo Civil nem com a Constituição Federal.

Assim, diante da escolha do constituinte pela preponderância da segurança jurídica, a coisa julgada deve ser passível de revisão, desde que limitada às hipóteses taxativas, prévia e legalmente estabelecidas, com prazo determinado e sempre com a observância do devido processo legal.

\section{REFERÊNCIAS}

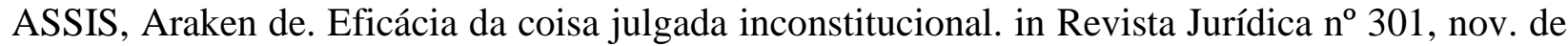
2002. Disponível em <http://amdjus.com.br/doutrina/civil/170.htm>. Compulsado em $15 / 08 / 2016$.

BUENO, Cassio Scarpinella. Novo Código de Processo Civil anotado. São Paulo: Saraiva, 2015.

CALDEIRA, Marcus Flávio Horta. Coisa Julgada e crítica à sua "relativização". Brasília: Thesaurus, 2012.

CÂMARA, Alexandre Freitas. Ação rescisória. 3 ed. São Paulo: Atlas, 2014.

CANOTILHO, José Joaquim Gomes. Direito constitucional e Teoria da Constituição. 7 ed. Coimbra: Almedina, 2003.

CUNHA, Leonardo Carneiro da. A Fazenda Pública em juízo. 10 ed. São Paulo: Dialética, 2012.

DELLORE, Luiz. Estudos sobre coisa julgada e controle de constitucionalidade. Rio de Janeiro: Forense, 2013. 
DIDIER, Fredie Jr. et al. Curso de Direito processual civil. V. 2. Salvador : Podivm, 2007.

DINAMARCO, Cândido Rangel. Relativizar a coisa julgada material. In: NASCIMENTO, Carlos Valder do. (org.). Coisa julgada inconstitucional. Rio de Janeiro: América Jurídica, 2003.

LIEBMAN, Enrico Tullio. Eficácia e autoridade da sentença e outros escritos sobre a coisa julgada. Tradução Alfredo Buzaid e Benvindo Aires. 4 ed. Rio de Janeiro: Forense, 2006.

MARINONI, Luiz Guilherme. Curso de processo civil. V. 2. Processo de conhecimento. 7 ed. São Paulo: Revistas dos Tribunais, 2008.

, Luiz Guilherme. Coisa julgada inconstitucional: a retroatividade da decisão de (in) constitucionalidade do STF sobre a coisa julgada - a questão da relativização da coisa julgada. São Paulo: Revista dos Tribunais, 2008.

MENDES, Gilmar Ferreira. A constitucionalidade do art. 27 da Lei n. 9.868/99. In: Rocha, Fernando Luiz Ximenes; MORAES, Filomeno (coords.). Direito constitucional contemporâneo: estudos em homenagem ao Professor Paulo Bonavides. Belo Horizonte: Del Rey, 2005.

MOREIRA, José Carlos Barbosa. Considerações sobre a chamada "relativização da coisa julgada material". In Revista Forense, Rio de Janeiro: Forense, v. 377, jan/fev. 2005.

MIRANDA, Pontes de. Tratado da ação rescisória - das sentenças e de outras decisões. Atualizado por Nelson Nery Junior e Georges Abboud. São Paulo: Revista dos Tribunais, 2016.

NERY JÚNIOR, Nelson. Código de processo civil comentado/ Nelson Nery Junior, Rosa Maria de Andrade Nery. 16 ed. São Paulo: Revista dos Tribunais, 2016.

PORTO, Sérgio Gilberto. Coisa julgada civil. 3 ed. São Paulo: Revista dos Tribunais, 2006.

SILVA, José Afonso da. Curso de direito constitucional positivo. 36 ed. São Paulo: Malheiros, 2013.

SILVA, Ovídio Baptista. Curso de processo civil. Vol. 1. Processo de conhecimento. 7 ed. Rio de Janeiro: Forense, 2006.

, Ovídio Baptista. Coisa julgada relativa? Academia Brasileira de Direito Processual. Estudo destinado ao livro-homenagem ao Prof. Giuseppe Tarzia da Universidade de Milão, por ocasião de seus 40 anos de docência universitária. Disponível em http://www.abdpc.org.br/abdpc/artigos/Ovidio\%20Baptista\%20-formatado.pdf. Compulsado em $15 / 08 / 2016$.

SOUZA, Bernardo Pimentel. Introdução aos recursos cíveis a à ação rescisória. 8 ed. São Paulo: Saraiva, 2011.

STF, ADI 1.753-2/DF. Relator Min. Sepúlveda Pertence. Disponível em http://redir.stf.jus.br/paginadorpub/paginador.jsp?docTP=AC\&docID=347250 .Compulsado em 16/08/2016. 
REPERCUSSÃO GERAL NO RE 730.462/SP. Relator Min. Teori Zavascky. Disponível em <http://redir.stf.jus.br/paginadorpub/paginador.jsp?docTP=TP\&docID=6250727>. Compulsado em 17/08/2016.

TARTUCE, Flávio. Impactos do novo CPC no direito civil. Rio de Janeiro: Forense, 2015.

WAMBIER, Teresa Arruda Alvim. Nulidades do processo e da sentença. 7 ed. São Paulo: Revista dos Tribunais, 2014.

Et al. Primeiros comentários ao novo código de processo civil: artigo por artigo. Coordenação Teresa Arruda Alvim Wambier. São Paulo: Revista dos Tribunais, 2015. 